\title{
Cycling of marine dissolved organic matter. II. A model analysis
}

\author{
Nicholas Blackburn ${ }^{1, *}$, Ulla Li Zweifel ${ }^{1}$, Åke Hagström ${ }^{2}$ \\ ${ }^{1}$ Institutionen för Mikrobiologi, Umeå University, S-901 87 Umeå, Sweden \\ ${ }^{2}$ Department of Marine Ecology and Microbiology, National Environmental Research Institute Fredriksborgvej 399 , \\ PO Box 358, DK-4000 Roskilde, Denmark
}

\begin{abstract}
Nutrient pathways within the microbial food web were analysed using a mechanistic model based on a multi-stage flow-through experimental system. Good agreement with measured values reflected the model's ability to function on 3 different orders of magnitude with respect to turnover time. Important observations made from the experimental system included the production of viruses, the presence of dead bacterial cells (ghosts), and the production of detritus. This led to the concept that the bacterial community forms a continuum from live uninfected cells through infected cells, dead cells, degraded cells (detritus) and ends in dissolved organic matter. Enzymatic degradation of dissolved organic matter was balanced by its release during cell lysis caused by viruses, predation by flagellates, and degradation of detritus. This formed 3 closed loops in the model for nutrient recycling. Simulations predicted that phosphorus recycling occurred via nucleic acids released during cell lysis caused by viruses and that nitrogen was recycled via proteins released as a combined result of cell lysis caused by viruses, predation by flagellates, and degradation of detritus. This implies that for natural ecosystems, the availability of nitrogen, phosphorus, and carbon species for bacterial growth can be dominated by internal recycling, depending on the molecular species in question and the turnover time. Different nutrients are made available by different processes of recycling which potentially occur on different time scales.
\end{abstract}

KEY WORDS: Dissolved organic matter recycling Microbial food web dynamics - Nutrient recycling Computer simulation Bacteria - Virus - Heterotrophic nanoflagellates B Bacterial ghosts

\section{INTRODUCTION}

Nutrient recycling within the microbial food web is channelled through a dissolved organic matter (DOM) pool (Azam et al. 1983). Sources of DOM include cell lysis and excretion from primary producers and grazers. Sinks are both abiotic (adsorption and particle formation; Kepkay \& Johnson 1988, Kepkay 1994) and biotic (bacterial consumption). The discovery of high virus numbers complicates the picture (Bergh et al. 1989, Proctor \& Fuhrman 1991). The flow of carbon within the microbial food web as a result of cell lysis caused by viruses has been estimated to be high (Bratbak et al. 1992, Fuhrman 1992). In support of this, it has been shown that viruses can cause a high rate of mor-

\footnotetext{
•E-mail: nicholas.blackburn@umf.umu.se
}

tality in heterotrophic and cyanobacteria as well as in phytoplankton (Proctor \& Fuhrman 1990, Suttle et al. 1990a). Recently, large fractions of dead bacterial cells have been observed in natural samples (Zweifel \& Hagström 1995). These observations imply a rapid turnover of bacteria with a small fraction of productive individuals. Nucleic acids and proteins released during cell lysis, and proteins and carbohydrates left in cell walls, are potentially important sources of DOM through which nutrients can be recycled (Proctor \& Fuhrman 1991, Fuhrman 1992). High rates of DOM degradation have been reported (Rosso \& Azam 1987, Kirchman et al. 1991, Turk et al. 1992, Zweifel 1993), confirming the feasibility of high regeneration efficiency. Seen in this perspective, the microbial loop really consists of multiple loops, which operate on different time scales and are responsible for the recycling of different nutrients. Consequently, an understanding 
of the enzyme dynamics, the molecular composition of the DOM pool, and the processes involved in releasing DOM become very important.

Typically, existing models have focused on the microbial food web in its entirety in an attempt to create a nutrient budget (Ducklow 1983, Hagström et al. 1988 , Suttle et al. 1990b, Taylor \& Joint 1990, Baretta-Bekker et al. 1994). This was at the expense of detail in regard to pathways for nutrients within the DOM stock, which has been treated as a 'black box'. This model study focuses on the subsystem of the food web consisting of heterotrophic bacteria and their interaction with heterotrophic nanoflagellates and viruses. DOM and cells were divided into the fundamental components of nucleic acids, phospholipids, proteins and carbohydrates in order to irace lite flow of carbon, nitrogen, and phosphorus. The model was based on a multistage flow-through experimental system decsribed in a companiory paper by Zweifel et al. (1996, in this issue).

\section{MODEL STRUCTURE}

The model could be imagined as consisting of 2 layers. The first consists of the pathways for internal nutrient recycling through dissolved inorganic stocks. The second consists of transport terms and simple population dynamics for the purpose of verification by the experimental system ( $Z$ weifel et al. 1996). This system was composed of 3 stages $\left(B_{0}, B_{1}\right.$, and $\left.B_{2}\right)$ containing stocks of bacteria and viruses. The last 2 stages were in duplicate, 1 set also containing heterotrophic nanoflagellates $\left(B F_{1}\right.$ and $B F_{2}$ ). Each stage had a different dilution rate. $B_{0}$ was supplied by a medium of autoclaved and filtered seawater. In this way the autotrophs were excluded from the experimental system and replaced with the inflow of DOM.

The model was described in terms of carbon flow. Nitrogen and phosphorus were parallel systems related to the flow of carbon by fixed C:N:P quotas for all molecular species, organisms, and particles (Table 1). This eased calculations somewhat and, although the C:N:P ratio and physiology of bacteria change under varying conditions, these changes are small in relation to the difference between live and dead cells (Neidhardt et al. 1990). Fig. 1 shows the carbon, nitrogen, and phosphorus cycles given conditions simulating the intermediate stage which included flagellates in the experimental system $\left(\mathrm{BF}_{1}\right)$. Rate constants and other parameters are given in Table 2 .

Stocks. When viewed as a flow diagram (Fig. $1 \mathrm{~A}$ ), the carbon flow formed 3 loops. The first two were the feedback of dissolved organic carbon (DOC) due to cell lysis by viral attack and direct excretion of DOC by flagellates. The third was the feedback of DOC due to the
Table 1. (A) Composition of molecules calculated from textbook averages. (B) Composition per unit dry weight for bacteria taken from Neidhardt (1990). (C) Composition of organisms per mole carbon calculated based on the carbon weight content of the molecules and the estimated composition per unit dry weight. Composition of the dissolved fraction after cell lysis (DOM $\mathrm{Ivs}_{\mathrm{vs}}$ ) calculated assuming a total content of $30 \%$ of the original cell's carbon. The resulting ghost contained the other $70 \%$, and its composition was adjusted to contain no nucleic acids but the majority of lipids and carbohydrates assumed to make up the cell wall. (D) C:N and C:P ratios of organisms calculated based on the composition of molecules per mole $\mathrm{C}$ and on the $\mathrm{C}: \mathrm{N}$ and $\mathrm{C}: \mathrm{P}$ ratios of the molecules

\begin{tabular}{|c|c|c|c|c|}
\hline \multicolumn{3}{|c|}{ (A) Composition of molecules } & $\mathrm{C}: \mathrm{P}$ & Weight (\% C) \\
\hline Protein & 3 & & & $48 \%$ \\
\hline Phos lin & & & 42 & $68 \%$ \\
\hline Nucl acid & 6.1 & & 9.75 & $35 \%$ \\
\hline Carbohyd & & & & $56 \%$ \\
\hline \multicolumn{5}{|c|}{ (B) Composition per unit dry wt } \\
\hline & Protein & Phos lip & Nucl acid & Carbohyd \\
\hline Bacteria & $45 \%$ & $10 \%$ & $20 \%$ & $25 \%$ \\
\hline Flagellates & $55 \%$ & $15 \%$ & $10 \%$ & $20 \%$ \\
\hline Ghosts & $47 \%$ & $15 \%$ & $0 \%$ & $38 \%$ \\
\hline \multicolumn{5}{|c|}{ (C) Composition per mol C } \\
\hline & Protein & Phos lip & Nucl acid & Carbohyd \\
\hline Bacteria & $44 \%$ & $14 \%$ & $14 \%$ & $28 \%$ \\
\hline Flagellates & $52 \%$ & $20 \%$ & $7 \%$ & $22 \%$ \\
\hline Ghosts & $42 \%$ & $19 \%$ & $0 \%$ & $39 \%$ \\
\hline $\mathrm{DOM}_{\mathrm{lys}}$ & $48 \%$ & $2 \%$ & $47 \%$ & $3 \%$ \\
\hline \multicolumn{2}{|c|}{ (D) Molar ratios } & \multicolumn{2}{|c|}{$\mathrm{C}: \mathrm{N}$} & $\mathrm{C}: \mathrm{P}$ \\
\hline Bacteria & \multicolumn{3}{|c|}{6} & 56 \\
\hline Flagellates & \multicolumn{3}{|c|}{5} & 85 \\
\hline Ghosts & \multicolumn{3}{|c|}{7} & 222 \\
\hline $\mathrm{DOM}_{\mathrm{yY}^{5}}$ & \multicolumn{3}{|c|}{4} & 20 \\
\hline
\end{tabular}

breakdown of a detritus stock consisting of degraded dead bacterial cells and flagellate egestion products DOC was itself divided into 4 components: carbohydrates (including lipids), nucleic acids, proteins, and phospholipids. Bacteria were divided into 3 stocks: uninfected live bacteria, virus-infected bacteria, and dead bacteria (ghosts). Ghosts were considered dead, empty cells composed mainly of bacterial cell walls resulting from cell lysis caused by viruses, and by definition visible for direct counts under a microscope (Zweifel \& Hagström 1995). The ghosts broke down to detritus, defined as being unidentifiable under a microscope but still particulate matter. Viruses were divided into 2 stocks: active and inactive (Suttle \& Chen 1992). The complex components of DOC degraded to carbohydrates, while the nitrogen and phosphorus contents entered inorganic nutrient stocks. These classes were not strict. Amino acids, which can be taken up directly by bacteria, were 
also included in the inorganic stocks, while being accounted for in the carbon budget. All degradation was a function of a pseudo-enzyme stock, meaning that the actual level was not explicitly simulated but that a certain functionality was, i.e. the level was regulated by biological activity, degradation, and flow.

Flows. The rates controlling the stocks are given in Table 3 and are referred to by number in the following text.

Enzymes: It was assumed that enzymes were released during cell lysis by viruses. The degradation of DOC was adjusted by setting the inflow of enzymes to the system proportional to the rate of cell lysis and the cube of the growth rate. The proportionality factor was the parameter 'Enzyme scale' (Eq. 1). The constant adjusted the enzyme stocks so that the rate constant for degradation was unity. The degradation factor for the enzymes themselves (Eq. 2) was set to the same as that for DOC (Eq. 3). The degradation of ghosts to detritus, detritus to $\mathrm{DOC}$, as well as virus inactivation and the disappearance of viruses were set in relation to the rate of DOC degradation (Eqs. 4, 5, 6 \& 7) by respective complexity factors (Table 2), allowing us to distinguish between, for example, free protein and cell-bound protein, the latter having a much more complex degradation process.

Bacteria: Bacteria utilised carbohydrates, inorganic nitrogen, and inorganic phosphorus for growth (Zweifel 1993). The rate of uptake was a Michaelis-Menten equation for the substrate that gave the lowest potential uptake of the three (Eq. 8) while maintaining the fixed $C: N: P$ ratio for a bacteria. It was assumed that growth of the bacterial stock was proportional to the stock's biomass. Bacteria respired a fixed fraction of carbon uptake (Resp frac $_{\text {bact }}$ ) in addition to that required for a basic metabolism (Resp $\mathrm{O}_{\text {baci }}$ ) (Eq. 9). Live and infected bacteria behaved almost identically, the exception being that infected bacteria had a reduced potential uptake regulated by a factor (Infect uptake) which was based on the assumption that a fraction of the infected population was in the advanced stages of phage production (Proctor et al. 1993, Weinbauer \& Peduzzi 1994). Ghosts did not metabolise.

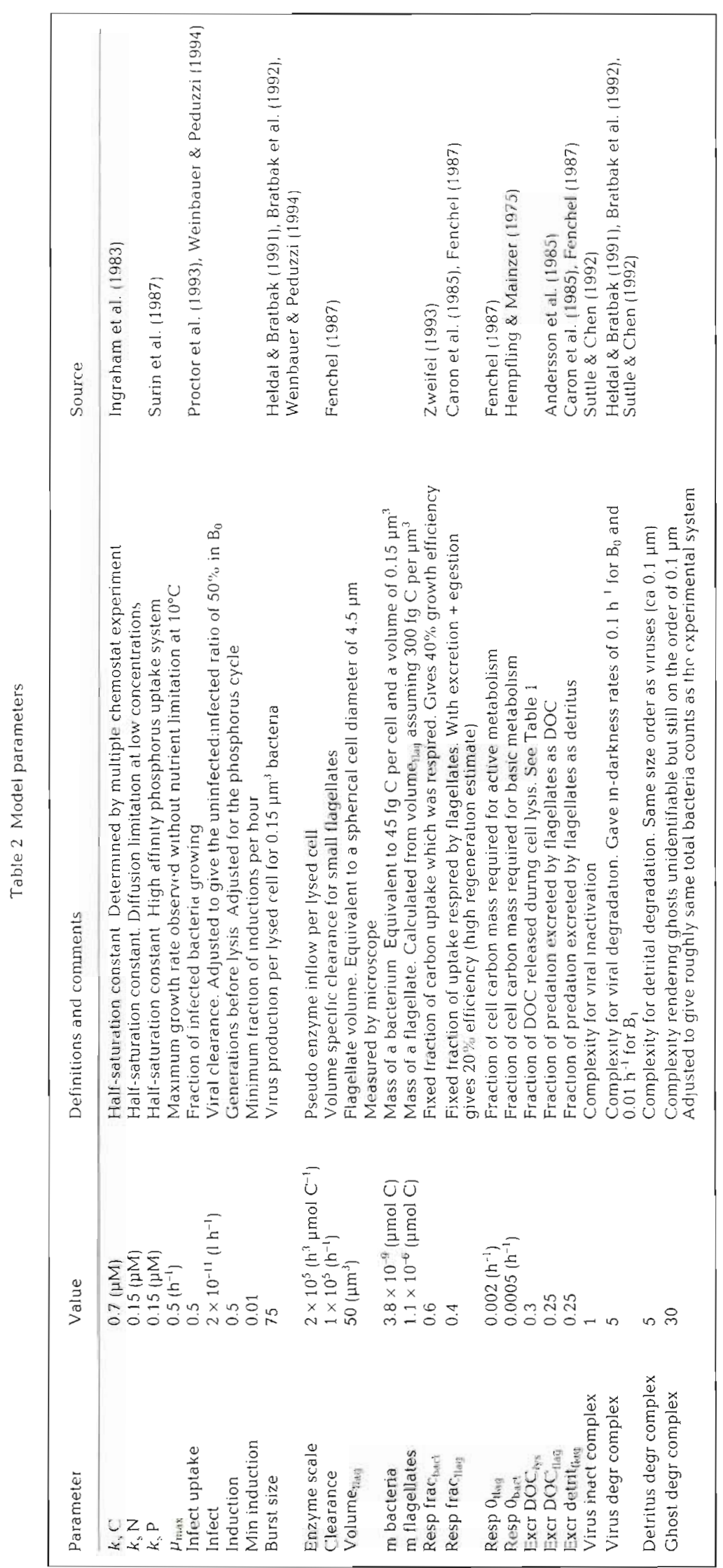



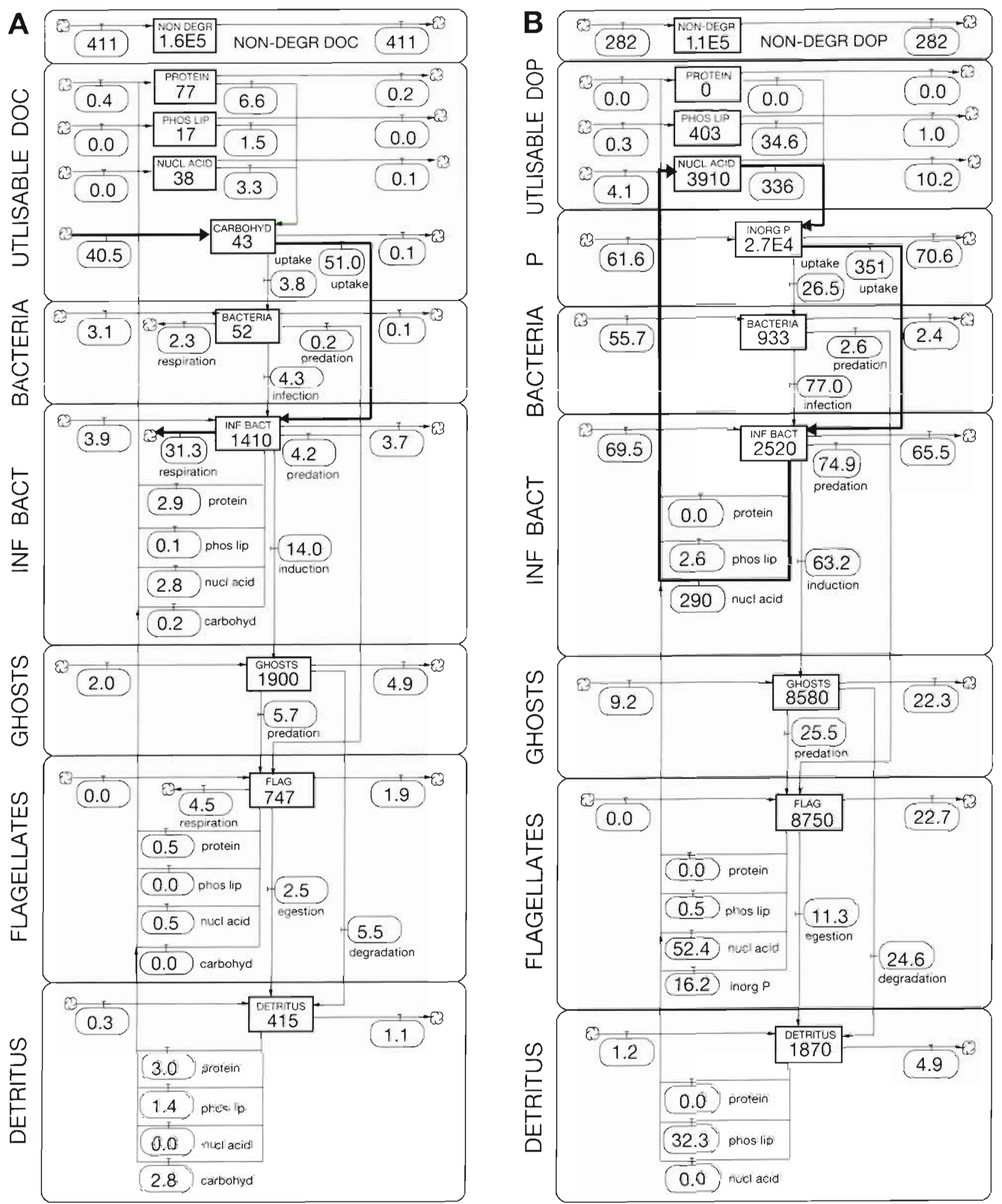

Fig. 1. Simulated values of flows and standing stocks of (A) carbon, (B) phosphorus, and (C) nitrogen for the intermediate stage of the experimental system which contained flagellates $\left(\mathrm{BF}_{1}\right)$. Flows between stocks (boxes) conserve mass. Cloud symbols ( 3 ) represent infinite sources or sinks and are used to simulate physical flows and respiration. Flow rates are attached to their respective arrows as 'valves' This is conventional System Dynamics notation. The most important flows are indicated with bold lines. Stocks of carbon and nitrogen are in units of nmol, flows in $n$ mol $h^{-1}$ Stocks of phosphorus are in units of pmol, flows in pmol $h^{-1}$ The equivalent volume of $\mathrm{BF}_{1}$ was 11 


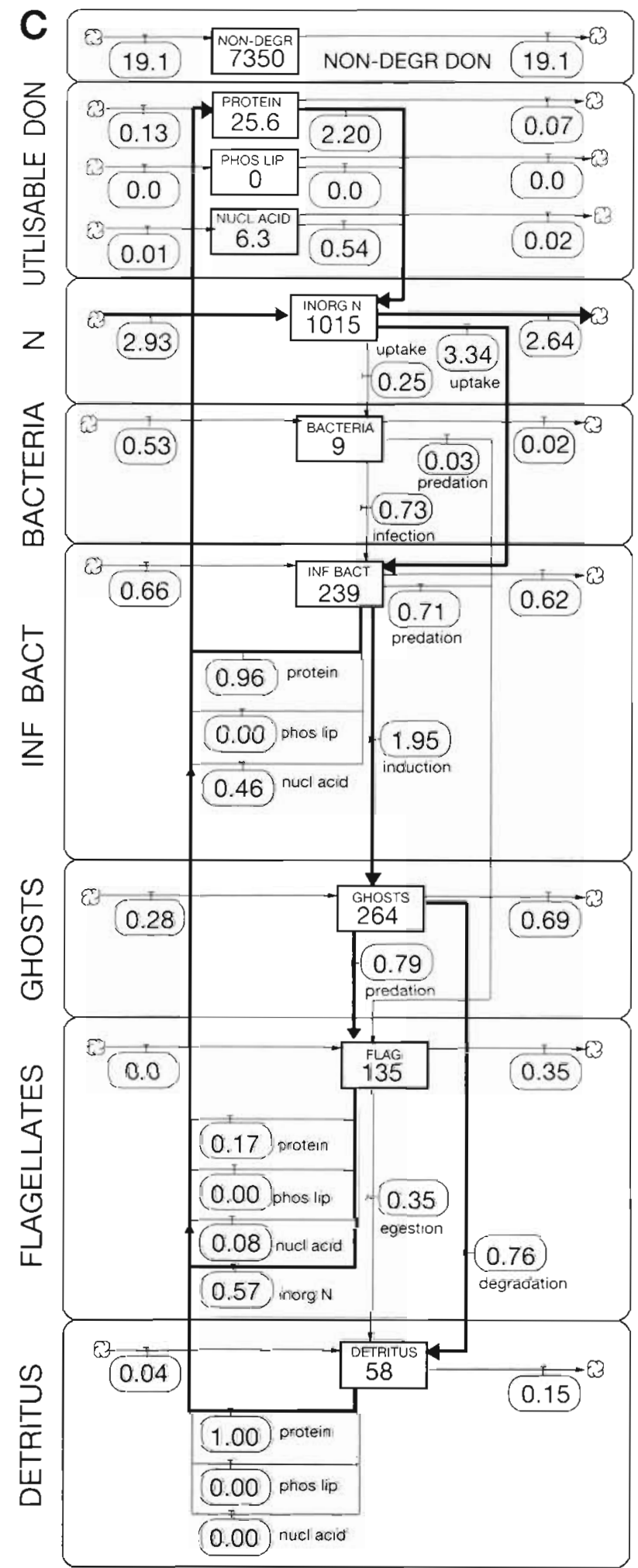

The rate of viral infection (Eq. 10) was proportional to the concentration of uninfected bacteria and active viruses by a factor (Infect). This is equivalent to the basic Lotka-Volterra assumption for a predator-prey situation and is a good approximation of reality when the rate of predation (Infection) is well below maximum capacity and the populations are homogeneously distributed in space. The maximum adsorption constant for cells of this size is on the order of 1 to $10 \times$ $10^{-11} 1 \mathrm{~h}^{-1}$ (Schwartz 1976). Virual concentrations in the experimental system were on the order of $1 \times 10^{10} \mathrm{I}^{-1}$, so the number adsorbing per hour per bacteria would be on the order of 0.1 to 1 , well below saturation.

Infected bacteria lysed at a rate proportional to the rate of bacterial growth by a factor (Induction) to become ghosts (Eq. 11). A minimum fraction (Min induction) was lysed to give the degree of independence of growth rate assumed in $B_{2}$ (see 'Results and discussion').

All 3 bacteria stocks were predated by flagellates (see 'Flagellates' below).

Viruses: The virus stock grew by a number (Burst size) for every infected bacterial cell lysed (Eq. 12). These became inactivated and subsequently degraded as a result of enzyme activity.

Flagellates: Flagellates fed upon all 3 bacteria stocks. Predation rates (Eq, 13) were proportional to predator and prey concentrations by a factor (Clearance), a volume specific maximum clearance rate, and the flagellate volume (Volume flag ). Saturation for predation occurs at ingestion rates of approximately 1 flagellate volume $\mathrm{h}^{-1}$ (Fenchel 1987). The condition that predation (ca 5 bacteria $\mathrm{h}^{-1}$ ) must be well below saturation was therefore met. Flagellates respired a fixed fraction (Resp $f \mathrm{ac}_{\mathrm{flag}}$ ) of uptake excluding egestion products in addition to that required for a basic metabolism (Resp 0 flag) (Eq. 14).

DOC: When an infected bacterial cell lysed, the components of DOC were conserved. Most of the nucleic acid was released as DOM, and most of the carbohydrates were retained in the resulting ghost. This assumes that the actual biomass of the viruses grown within the host cell account for only a fraction of the cell's contents. The volume of a virus particle is

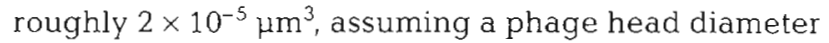
of $50 \mathrm{~nm}$ (Weinbauer \& Peduzzi 1994), i.e. 2000 times smaller than a bacteria. A burst size of 75 (Table 2) would account for only about $4 \%$ of the total bacterial mass and at most $10 \%$ of the nucleic acid. Given the composition of ghosts and an estimate of the fraction of DOC released during cell lysis (Excr DOC $\mathrm{Cys}_{\mathrm{s}}$ ), it was possible to calculate the composition of the released DOC (Table 1). The rate of DOC release was the rate of cell lysis multiplied by the fraction of DOC released per lysed cell (Eq. 15).

For simplicity, the same composition of released DOC was assumed for excretion by flagellates. The rate of excretion was a fraction (Excr DOC flag) of predation on the active fraction of bacteria (Eq. 16). Excretion of predation on ghosts was excluded to avoid a deficit in the flagellate C:N:P quota with the present 


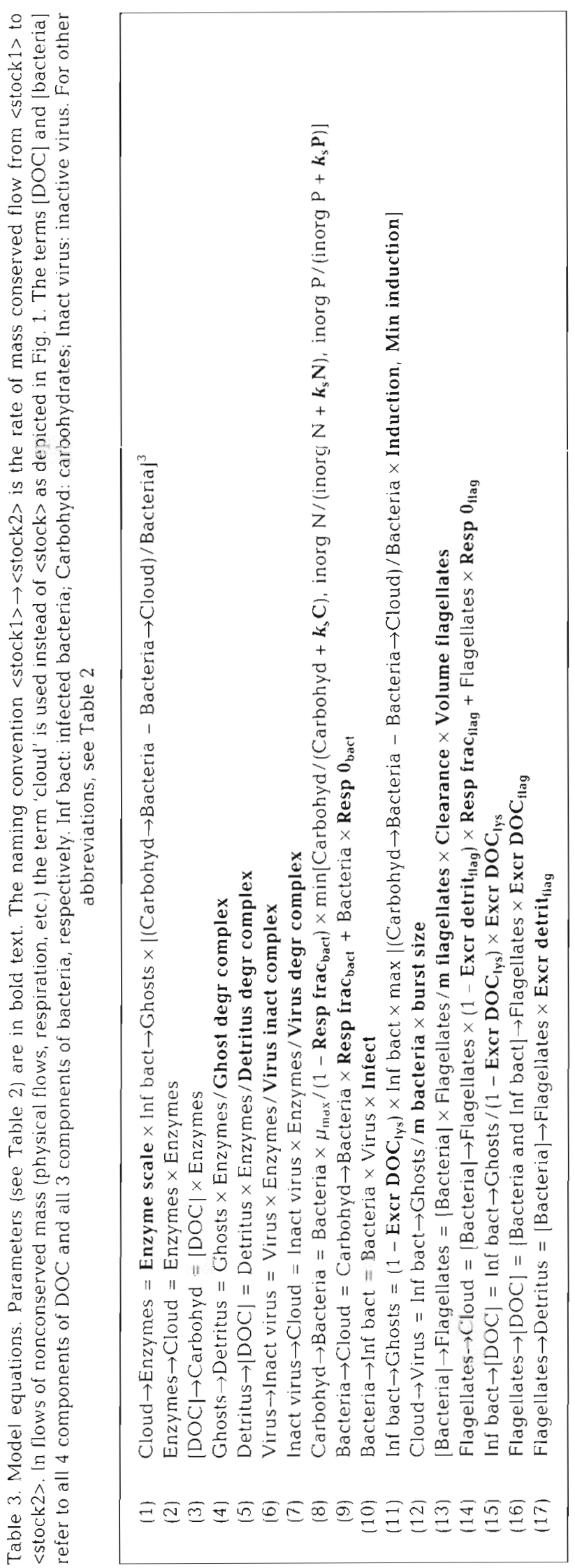

parameters. A fixed fraction (Excr detrit $t_{\text {flad }}$ ) of egestion products entered the detritus stock (Eq. 17)

Inorganic nutrients: The amount of inorganic nitrogen and phosphorus released during predation was calculated as the difference between the sum of all inflows and outflows to the flagellate stock and the amount needed to maintain the fixed $\mathrm{C}: \mathrm{N}: \mathrm{P}$ ratio for flagellates.

Degradation of DOM to inorganics (small molecules), controlled by the enzyme stock (Eq. 3), could be calculated as the sum of the rates of each DOC component divided by their respective $\mathrm{C}: \mathrm{N}$ or $\mathrm{C}$ : $\mathrm{P}$ ratios.

Depletion of the inorganic nitrogen and phosphorus stocks by bacterial growth was calculated as the net carbon uptake divided by the bacterial $C: N$ and $C: P$ ratio, respectively.

Simulation. Flows in the experimental system were simulated by inflows and outflows for each stock in the model. In order to simulate the different situations in the different stages, 2 simple steps were taken: (1) The rate of inflow was adjusted according to the dilution rate of the stage. (2) Resulting stocks from the previous run (previous stage or medium in the case of $B_{0}$ ) were used to calculate the inflows. The latter step ensured that the whole experimental system was simulated; no measured values or estimates were incorporated between simulations.

Graphs of stocks were plotted during simulations which were run until equilibrium was obtained. This could easily be verified visually as all stocks approached equilibrium asymptotically. For a discussion of the steady state conditions of the experimental system, see the companion paper (Zweifel et al. 1996).

The model in an executable version is accessible via the Internet at (http://www.dmu.dk/PublicFiles/Documents/DomModel/). The parameters (Table 2) and equations (Table 3 ) give a complete description of the model except for the bookkeeping involved in simulating the flows of nitrogen and phosphorus. A description of the entire model in text format is also available at the same address.

\section{RESULTS AND DISCUSSION}

The importance of this model lies in its interpretation of the speed of nutrient recycling within the microbial food web via dissolved organic molecules and in its ability to demonstrate how carbon, nitrogen and phosphorus can be channelled through these molecules The pathways for carbon, nitrogen and phosphorus for bacterial growth were different (Fig. 1). Although the figures show the simulated flows from $\mathrm{BF}_{1}$, the relative magnitudes of the flows were much the same in all stages with a few exceptions. Basically, carbon was 
supplied to the system and respired (Fig. 1A). Phosphorus was supplied through cell lysis caused by viruses via a single closed loop and stocks which were rapidly turning over (Fig. 1B). The pathways for nitrogen were more complex and occurred mainly via protein (Fig. 1C). It could be argued that the model can be simplified and limited to these main flows when either carbon, nitrogen, or phosphorus is of interest.

The relative magnitudes of the simulated carbon flows (Fig. 1A) are in contrast to those calculated by Bratbak et al. (1992), who estimated a large feedback of carbon through DOC stocks as a result of viral activity on bacteria. The relative magnitudes of their budget would correspond better to our estimates for the nitrogen cycle (Fig. 1C).

The DOC degradation factor followed changes in the dilution rates, while the changes in bacterial growth rates were less dramatic (Table 4). These simulation results were due to a complex combination of changing nutrient sources and changing fractions of living versus dead or infected bacterial biomass, from a mostly active $\left(80 \%\right.$ growing) community in $\mathrm{B}_{0}$ to an almost dead community in $\mathrm{B}_{2}$ a community containing only a few live and growing bacteria.

This model was the implementation of a conceptual model of how the food web in the experimental system was thought to function. In modelling, a good fit can be the result of parameter adjustment, an exercise which may be of limited value. However, interpreted in an ecological context, comparisons between simulated and measured standing stocks under different conditions may be used to evaluate the behavior of the model structure. A comparison is shown in 'Standing stocks' below in order to illustrate trends and to show that stocks could be reproduced in a satisfactory manner. By this we mean that values for simulated stocks were close to measured values despite rates which changed by 2 orders of magnitude (Table 4 ) and, in many cases, despite high turnover frequencies for stocks (Table 5). When discussing this model and ones similar to it, it is possible to focus on model structure and realism of parameters while trusting the literature

Table 4. Resulting DOC degradation factors (equivalent to the enzyme stock) and net bacteria growth rates from simulations of the 5 stages in the flow-through experimental system with different dilution rates

\begin{tabular}{|lccccc|}
\hline & $\mathrm{B}_{0}$ & $\mathrm{~B}_{1}$ & $\mathrm{~B}_{2}$ & $\mathrm{BF}_{1}$ & $\mathrm{BF}_{2}$ \\
\hline $\begin{array}{l}\text { Dilution rate }\left(\mathrm{h}^{-1}\right) \\
\text { DOC degrad }\end{array}$ & 0.03 & 0.0026 & 0.00052 & 0.0026 & 0.00052 \\
factor $\left(\mathrm{h}^{-1}\right)$ & 0.45 & 0.055 & 0.0054 & 0.086 & 0.0067 \\
$\begin{array}{l}\text { Bacteria growth } \\
\text { rate }\left(\mathrm{h}^{-1}\right)\end{array}$ & 0.068 & 0.019 & 0.0058 & 0.028 & 0.0069 \\
\hline
\end{tabular}

Table 5. Estimated turnover frequencies of selected stocks within the physical turnover time of the different stages of the experımental system, excluding contributions due to physical flows

\begin{tabular}{|lccccc|}
\hline & $\mathrm{B}_{0}$ & $\mathrm{~B}_{1}$ & $\mathrm{~B}_{2}$ & $\mathrm{BF}_{1}$ & $\mathrm{BF}_{2}$ \\
\hline Bacteria & 2 & 7 & 11 & 11 & 13 \\
Inf bact & 1.1 & 4 & 5 & 5 & 6 \\
Ghosts & 1.5 & 1.5 & 0.5 & 3 & 1.6 \\
Flagellates & - & - & - & 1.0 & 0.0 \\
Virus & 16 & 22 & 10 & 34 & 12 \\
Nucl acids & 15 & 21 & 10 & 33 & 13 \\
Protein & 15 & 21 & 10 & 33 & 13 \\
Inorg N & 0.7 & 1.2 & 0.3 & 1.0 & 0.2 \\
Inorg P & 1.1 & 11 & 1.2 & 5 & 0.6 \\
\hline
\end{tabular}

to supply parameter values and a computer to perform correct integrations. The model's robustness as regards changes in parameters was tested in a sensitivity analysis (Table 6) in which key parameters were changed $\pm 50 \%$ in a simulation of $\mathrm{BF}_{1}$. The model was highly insensitive to all but flagellate clearance and (to a lesser degree) bacterial respiration. This was due to feedback loops in the model. In contrast, feedback via flagellate activity was relatively weak (Fig. 1), especially during phosphorus limitation. This reflected the lack of higher trophic levels as a stabilising factor in the ecosystem structure.

\section{Standing stocks}

\section{Bacteria}

The trend in the simulated bacteria counts followed those measured by epifluorescence microscopy (Fig. 2). The simulated population was the sum of uninfected, infected and dead cells (Fig. 3A). The stock of live cells (Fig. 3) was much less than that of nucleoid-containing cells in $B_{2}$ (Zweifel et al. 1996). A possible explanation for this is that a large fraction of nucleoid-containing cells were either non-growing or were undergoing

Table 6 . Sensitivity analysis. Percent change in the simulated bacteria counts as a result of running simulations of $\mathrm{BF}_{1}$, changing key parameters by $\pm 50 \%$

\begin{tabular}{|lrr|}
\hline Parameter & $-50 \%$ & $+50 \%$ \\
\hline Induction & $2 \%$ & $-4 \%$ \\
Burst size & $-1 \%$ & $1 \%$ \\
Infect & $-1 \%$ & $1 \%$ \\
Enzyme scale & $1 \%$ & $-1 \%$ \\
$\mu_{\max }$ & $0 \%$ & $4 \%$ \\
Clearance & $-68 \%$ & $32 \%$ \\
Resp frac & $-7 \%$ & $15 \%$ \\
\hline
\end{tabular}


advanced stages of viral infection. The simulated active community in $B_{2}$ was growing at a rate of $5.8 \times$ $10^{-3} \mathrm{~h}^{-1}$ (Table 4) compared to the minimum carbon uptake considered necessary for basic metabolism, i.e. $5 \times 10^{-4} \mathrm{~h}^{-1}$ (Table 2). This was a result of virus lysis keeping the numbers of active bacteria low and fuelling growth through recycling. The live population grew many times faster than the dilution rate (Table 5).
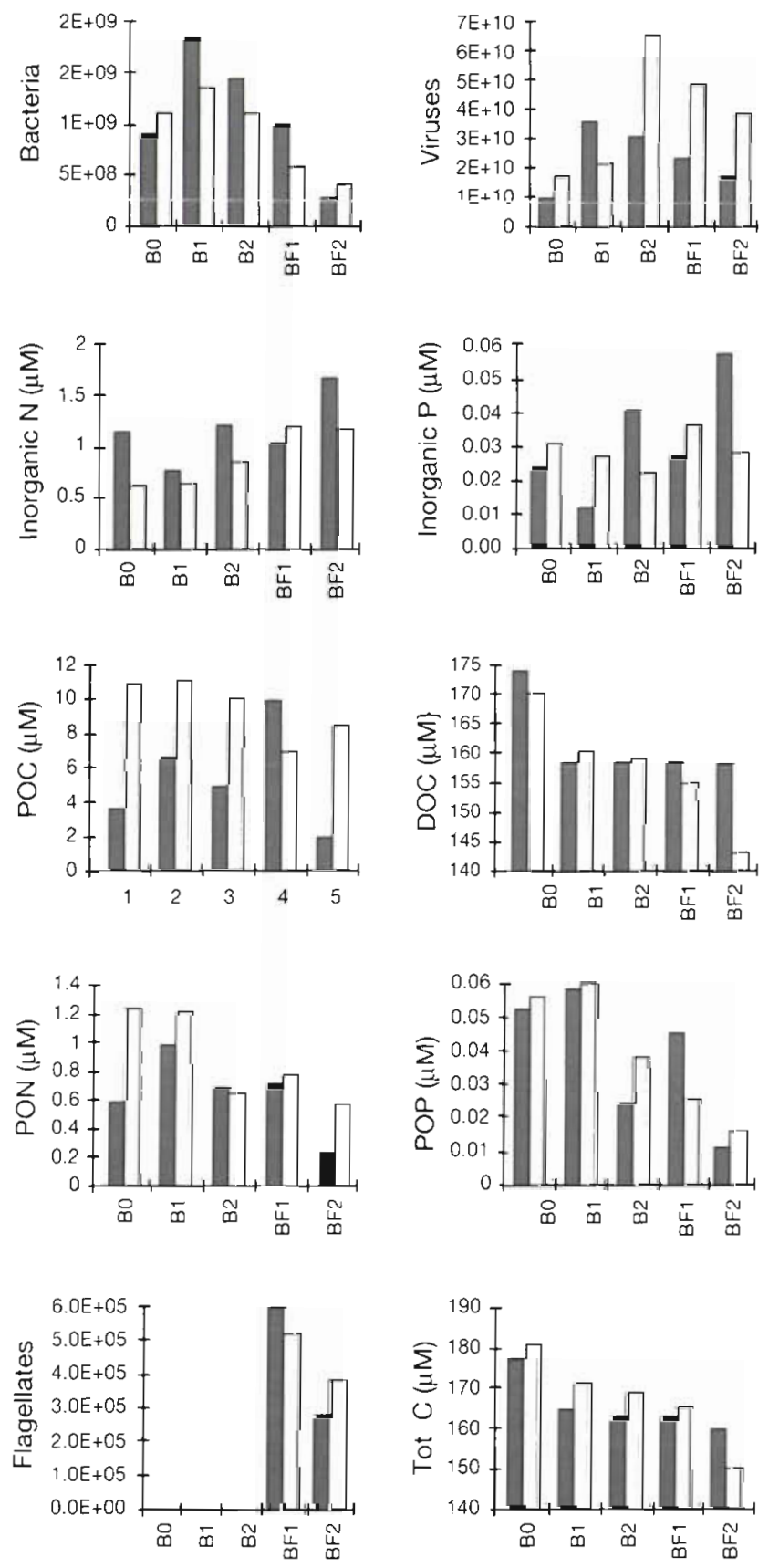

Fig. 2. Simulated (dark) and measured (light) values of standing stocks from all stages of the experimental system. Substrates are in units of $\mu \mathrm{MC}, \mathrm{N}$ or $\mathrm{P}$, organisms in no. $\mathrm{l}^{-1}$
Flagellates

Predation rates in $\mathrm{BF}_{1}$ and $\mathrm{BF}_{2}$ were 0.013 and 0.0034 flagellate cell masses $\mathrm{h}^{-1}$, respectively. Given the estimate for basic metabolism of $0.002 \mathrm{~h}^{-1}$ (Table 2), they were already growing under poor conditions in $\mathrm{BF}_{1}$ and were likely to have been starving in $\mathrm{BF}_{2}$. The simulated flagellate numbers represented actively foraging individuals, so the numbers in $\mathrm{BF}_{2}$ represented the maximum number able to maintain their basic metabolism.

\section{Viruses}

The simulated virus counts were reldively low for the stages with longer turnover times and for those containing flagellates. The high observed virus counts in $B_{2}$ (Fig. 3) were probably the result of infected bacterial cells coming from $B_{1}$ and releasing viruses, in conjunction with low degradation rates. This is supported by the high concentrations of phospholipids measured in $B_{2}$ (Zweifel et al. 1996). The bacterial growth rate was so low in $\mathrm{B}_{2}$ that cell lysis of infected cells was simulated independently of the growth rate (Eq. 11). The low active bacteria numbers in Fig. 3A (simulated) were thus believed to have resulted in the highest possible virus production with the given burst size. The underestimations of the virus levels in $B_{2}$ would therefore indicate that virus degradation was overestimated rather than that production was underestimated. Underestimations in the presence of flagellates was also interpreted as degradation being too high in relation to production; as growth increased, so did virus production as well as degradation but at a slightly wrong ratio. The decomposition to production ratios in the simulations were roughly unity but increased slightly with turnover time. The growth rate was estimated to be many times the dilution rate in all stages of the system (Table 5).

In the experimental system, virus direct counts were higher in $B F_{1}$ than in $B_{1}$ but lower in $B_{2}$ than in $B_{2}$, indicating no simple response in virus production due to the presence of flagellates. An increase in virus production per bacteria $\left(40 \%\right.$ in $\mathrm{BF}_{1}$ relative to $\mathrm{B}_{1}$ ) was predicted by simulations, as would be expected due to increased nutrient recycling, which results in increased specific bacterial growth and thereby increased potential virus production. Since viruses and flagellates are in competition, this emphasises the importance of nutrient recycling as a driving force for growth. Simulations of $\mathrm{BF}_{2}$ gave only the same production rate as $\mathrm{B}_{2}$ due to starvation conditions for the flagellates.

The estimated induction rate can give a clue to the dominance of temperate or virulent phage. The pro- 

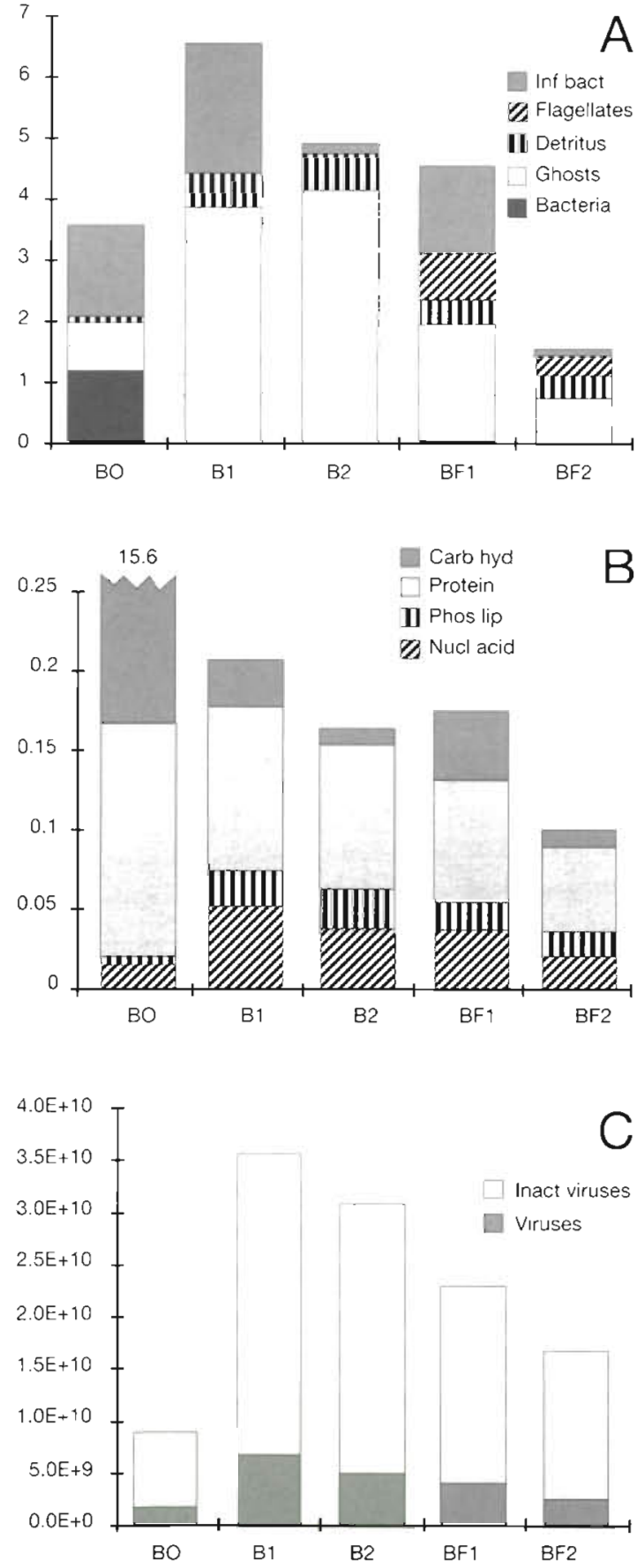

Fig. 3. Simulated compositions of standing stocks. (A) Particulate carbon in $\mu \mathrm{M},(B)$ DOC in $\mu \mathrm{M}$ showing the value of carbohydrates estimated in $B_{0}$ to be $15.6 \mu \mathrm{M},(\mathrm{C})$ active and inactive viruses in no. $\mathrm{I}^{-1}$

portionality factor is an estimate of the number of generations likely to occur before lysis (Eq. 11). These simulations suggested dominance of virulent stocks due to the necessarily high rate of induction in relation to bacterial growth rate.
The adsorption constant can be interpreted as a combined result of the ability of an individual virus to make contact and adsorb to a host cell, and the number of different species of host bacteria and host-specific virus present. Given a number (n) of different species of roughly equal abundance and their specific viruses also of roughly equal abundance, the adsorption constant for the whole community will be equal to that for a single species divided by $\mathrm{n}$ (Eq. 10 as a sum of $\mathrm{n}$ equally large subpopulations). As mentioned in the model description, the maximum can be calculated to be on the order of 1 to $10 \times 10^{-11} \mathrm{l} \mathrm{h}^{-1}$ The value of $2 \times$ $10^{-11}$ used in these simulations would indicate approximately 1 to 10 different dominant species and phagespecific hosts. Interestingly, this corresponded well to the number of visibly different morphologies observed in viable counts on solid media (Zweifel et al. 1996). Estimates could be improved with more knowledge of the actual frequencies of infected cells and the role they play in taking up nutrients and respiring carbon. In these simulations, there was a dominance of infected bacteria over uninfected bacteria (Fig. 3A).

\section{Particulate matter}

This was in practice a concept defined by a finite filter size; particles smaller than a given filter size $(0.2 \mu \mathrm{m})$ were assigned to the dissolved fraction, and those larger than this to the particulate fraction. In actual fact, material is a continuum of size fractions ranging from complete cells to dissolved organic molecules (Azam et al. 1993). In the model, the DOC stock was defined as being composed of molecules. The model handled the degradation of different size fractions with rates relative to that of DOC for the 2 size categories, cells and detritus (Table 2), which could be interpreted as an estimate of the complexity of enzyme attack in relation to DOC mineralization. Simulations predicted lower particulate organic carbon (POC) values than those measured (Fig. 2). It was concluded that detrital carbon made up the largest pool of POC in all culture vessels (Zweifel et al. 1996); however, the question of whether this carbon was produced by biological acitivity or by abiotic processes was not resolved.

\section{Dissolved organic matter}

Fig. 3B shows simulated values for proteins, nucleic acids, and phospholipids. The low concentrations of nucleic acids and phospholipids (Zweifel et al. 1996) were predicted although certain trends were not. These inaccuracies should be seen in light of the 
predicted high turnover frequencies of these stocks (Table 5) and the necessity to make rough estimations of composition. The majority of utilisable dissolved organic nitrogen (DON) was accounted for by protein, and the majority of utilisable dissolved organic phosphorus (DOP) by nucleic acids. The stability in the size of the stocks over 2 orders of magnitude in turnover times (and degradation rates) was due to the feedback mechanisms of the loops. DOC was estimated to be composed mostly of carbohydrates in $\mathrm{B}_{0}$ (Fig, 3B), which became the main source of carbon for $B_{1}$ in simulations (Fig. 1A), before becoming depleted in $\mathrm{B}_{1}$ (Fig. 3B). Table 7 gives an estimation of the composition of the media. The utilisable DOM was only a small fraction of the total DOM, while most was not degradable by enzymes. Fiy. 2 shiuws only a slight decrease in $\mathrm{DOC}$ in $\mathrm{B}_{2}$ after having gone through $\mathrm{B}_{1}$, despite high values of available nitrogen and phosphorus. The same applied to the total carbon. This meant that almost all the utilisable carbon was used up in $B_{1}$ and DOC in $B_{2}$ was assumed to be the non-degradable fraction. The further degradation of DOC and total carbon observed due to the presence of flagellates in $\mathrm{BF}_{2}$ (Fig. 2) is discussed in a companion paper (Zweifel et al. 1996), while no mechanism to simulate this was implemented in the model.

\section{Inorganic nutrients}

Characteristic of the inorganic nitrogen levels were their high values (Fig. 2) in relation to the half-saturation constant for bacteria (Table 2). This was calculated to be a result of uptake rates balancing degradation of DOM and inflow. Consistentiy high concentrations of inorganic nutrients were the result of a change in abundance and viability of the bacterial community (and thereby a change in consumption rates), which countered the effect of decreasing nutrient supply with turnover time. This change was the result of virus and flagellate control taking effect via the feedback loops in the model. The same applied to phosphorus although

Table 7. Estimated composition of the media based on the major classes of organic molecules making up the utilisable fraction of dissolved organic matter (DOM). DOC in units of $\mu \mathrm{M} C, \mathrm{DON}$ in $\mu \mathrm{MN}$, DOP in $\mu \mathrm{M} \mathrm{P}$

\begin{tabular}{|lccc|}
\hline & DOC & DON & DOP \\
\hline Protein & 2.0000 & 0.6667 & - \\
Nucleic acid & 0.0116 & 0.0019 & 0.0012 \\
Phospholipid & 0.0232 & - & 0.0006 \\
Carbohydrates & 24.0000 & - & - \\
Total utilisable & 26.0348 & 0.6686 & 0.0018 \\
Non-degradable & 158 & 6.66 & 0.107 \\
& & & \\
\hline
\end{tabular}

this was at levels well below the half-saturation constant for uptake by the bacteria. In particular, the phosphorus cycle simplified to a single closed loop (Fig. 1B), all rates of flow around which must be equal in equilibrium. meaning that DOP mineralization, phosphorus uptake, and cell lysis were all nearly equal in magnitude. Together with the known values of standing stocks, this fact was used to adjust parameters such as cell lysis and degradation factors (Table 2).

\section{Rates of flow}

\section{Sources of DOM}

An examination of the fraction of DOM belonging to proteins, nucleic acids, and phospholipids (Table 8A) revealed that the relative magnitude of the rates of recycling did not change with dilution rate. Thus, the scenario seen in Fig. 1 regarding proteins, nucleic acids, and phospholipids as channels for inorganic nutrients and carbon was the same for all stages in the experimental system. An exception to this was the high inflow of protein from the medium into $B_{0}$, which represented a major source of nitrogen but a negligible

Table 8 . Simulated rates of the most important nutrient flows for the flow-through experimental system as percentages of the sum. (A) Supplies of dissolved organic matter (DOM). (B) Supplies of carbohydrates for bacterial growth. (C) Supplies of inorganic nitrogen for bacterial growth. (D) Supplies of inorganic phosphorous for bacterial growth. The most significant flows are boxed

\begin{tabular}{|c|c|c|c|c|c|}
\hline Flow & $B_{n}$ & $\mathrm{~B}_{1}$ & $\mathrm{~B}_{2}$ & $\mathrm{BF}_{2}$ & $\mathrm{BF}_{2}$ \\
\hline \multicolumn{6}{|l|}{ (A) DOM } \\
\hline Inflow $\rightarrow$ Protein & 75 & 4 & 6 & 3 & 6 \\
\hline Detritus $\rightarrow$ Phos lip & 2 & 11 & 15 & 12 & 15 \\
\hline Detritus $\rightarrow$ Protein & 5 & 25 & 33 & 26 & 33 \\
\hline Inf bact $\rightarrow$ Nucl acid & 9 & 30 & 23 & 25 & 20 \\
\hline Inf bact $\rightarrow$ Protein & 9 & 31 & 23 & 25 & 20 \\
\hline Flagellates $\rightarrow \mathrm{Nucl}$ acid & 0 & 0 & 0 & 4 & 2 \\
\hline Flagellates $\rightarrow$ Protein & 0 & 0 & 0 & 5 & 2 \\
\hline \multicolumn{6}{|l|}{ (B) Carbohydrates } \\
\hline Inflow $\rightarrow$ Carbohyd & 90 & 77 & 1 & 74 & 3 \\
\hline Detritus $\rightarrow$ Carbohyd & 0 & 4 & 24 & 5 & 23 \\
\hline Nucl acid $\rightarrow$ Carbohyd & 1 & 6 & 19 & 6 & 18 \\
\hline Phos lip $\rightarrow$ Carbohyd & 0 & 2 & 12 & 3 & 12 \\
\hline Protein $\rightarrow$ Carbohyd & 8 & 11 & 44 & 12 & 44 \\
\hline \multicolumn{6}{|l|}{ (C) Inorganic nitrogen } \\
\hline Inflow $\rightarrow$ inorg $N$ & 58 & 55 & 66 & 47 & 64 \\
\hline Flagellates $\rightarrow$ inorg $N$ & 0 & 0 & 0 & 9 & 19 \\
\hline Nucl acid $\rightarrow$ inorg $N$ & 2 & 9 & 6 & 9 & 3 \\
\hline Protein $\rightarrow$ inorg $N$ & 40 & 36 & 28 & 35 & 14 \\
\hline \multicolumn{6}{|l|}{ (D) Inorganic phosphorus } \\
\hline Inflow $\rightarrow$ inorg $P$ & 75 & 16 & 20 & 14 & 37 \\
\hline Flagellates $\rightarrow$ inorg $\mathrm{P}$ & 0 & 0 & 0 & 4 & 17 \\
\hline Nucl acid $\rightarrow$ morg $P$ & 24 & 77 & 69 & 75 & 40 \\
\hline Phos lip $\rightarrow$ inorg $\mathrm{P}$ & 2 & 7 & 10 & 8 & 5 \\
\hline
\end{tabular}


source of carbon compared to that accounted for by carbohydrates. Apart from this, the flow of nitrogen occurred almost entirely via protein from both detritus and cell lysis (Table 8A). The flow of phosphorus occurred mainly via nucleic acids released during cell lysis by viruses (Table 8A). Carbon was recycled mainly via protein and nucleic acids released during cell lysis, and via protein and carbohydrates coming from the degradation of detritus (Table $8 \mathrm{~A}, \mathrm{~B}$ ). Phospholipids played a minor role in nutrient recycling.

Inflow dominated as a source of DOC in the form of carbohydrates for all stages in the experimental system except for the last two $\left(\mathrm{B}_{2}\right.$ and $\left.\mathrm{BF}_{2}\right)$, at which point all carbon had been respired and growth was maintained via recycled carbon (Table $8 \mathrm{~B}$ ).

\section{DOM mineralization}

The mineralization of DOM was very closely coupled to the supply of DOM via recycling, since the stocks of DOM components were small but quickly turning over. Thus, the flows of nitrogen and phosphorus via the mineralization of DOM also occurred via proteins and nucleic acids, respectively (Table $8 \mathrm{C}, \mathrm{D}$ ). The simulated DON and DOP turned over many times in all stages (Table 5). About $60 \%$ of the nitrogen was supplied by inflow and $40 \%$ by recycling, while for phosphorus the majority was supplied via recycling in all stages except $B_{0}$, where inflow from the medium was the major source (Table $8 \mathrm{C}, \mathrm{D}$ ).

Flagellate excretion of inorganic compounds

The relative amount of inorganic nitrogen and phosphorus estimated to be excreted directly by flagellates was small in relation to the amounts estimated to be due to DOM mineralization (Table 8C, D), except in the case of $\mathrm{BF}_{2}$, where flagellates fed mainly on phosphorus-poor ghosts (Fig. 3A) resulting in high excretion rates of inorganic nitrogen.

\section{Ecological implications}

Imagine a water-column where $B_{0}$ represents surface water with rapid ( 1 d) turnover, $B_{1}$ deeper water with turnover times on the order of $10 \mathrm{~d}$, and $\mathrm{B}_{2}$ deep water with turnover times of months. The flow of filtered sterile seawater to the first vessel, $B_{0}$ represents the internal supply of DOM to the heterotrophic part of the microbial food web. The increasing residence time is achieved by pumping the outflow to vessels of increasing size, simulating a downward transport due

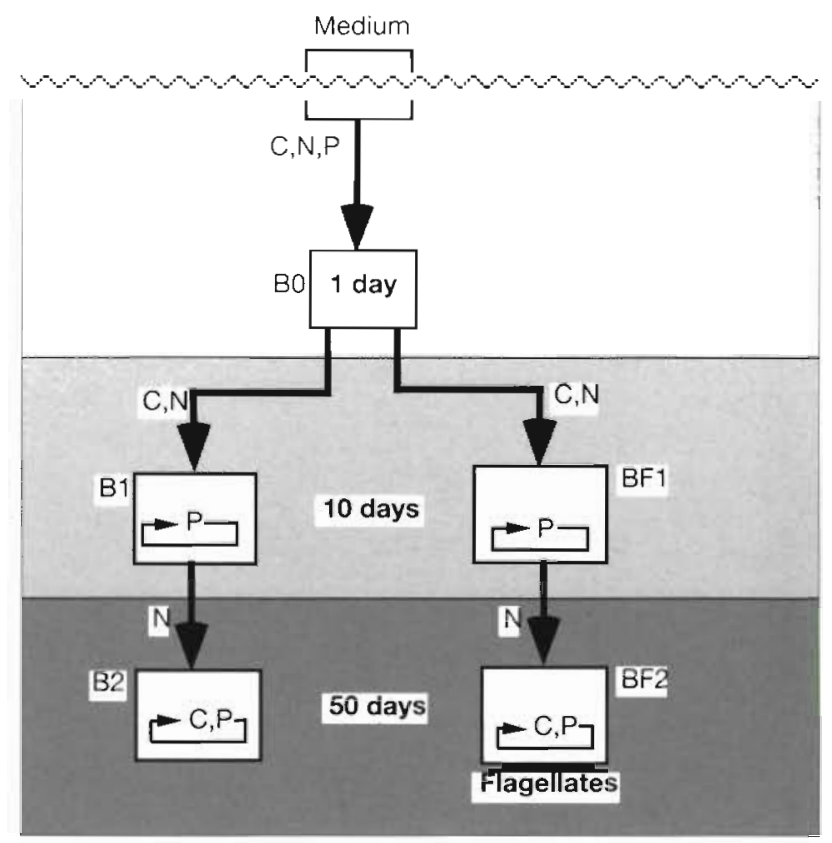

Fig. 4. Schematic diagram of the experimental system representing a heterotrophic microbial food web. Medium flowed into $\mathrm{B}_{0}$ which contained bacteria and viruses. $\mathrm{B}_{0}$ flowed along 2 arms to $B_{1}$ and $B F_{1}$ (the latter of which contained flagellates). $B_{1}$ and $B F_{1}$ then flowed into $B_{2}$ and $B_{2}$, respectively Mean residence times are indicated. The system could be thought to represent an oceanic profile. This study concluded that certain nutrients were recycled (shown inside the boxes) and some were transported (between boxes)

to turbulent mixing. The magnitude of such mixing can decrease roughly 2 orders, equivalent to the flows in the experimental system (Jumars et al. 1993). This scenario is summed up in Fig. 4.

The model analysis shows that the carbon, nitrogen and phosphorus in $\mathrm{B}_{0}$ were largely supplied from outside the heterotrophic part of the microbial food web. In $\mathrm{B}_{1}$ and $\mathrm{BF}_{1}$, phosphorus could feasibly have been supplied via recycling within the heterotrophic food web itself. In the cases of $\mathrm{B}_{2}$ and $\mathrm{BF}_{2}$, all nutrients could have been recycled, assuming a small population of active bacteria. Both bacteria and viruses went through several generations in all stages (Table 5), although growth in $\mathrm{B}_{2}$ and $\mathrm{BF}_{2}$ was so low that transport of organisms contributed somewhat to maintaining stocks (Table 9). When comparing the importance of virus as opposed to flagellates for the regeneration of inorganic nutrients, our model data suggests, in particular for phosphorus, that virus lysis and subsequent enzymatic degradation plays a dominant role. However, this conclusion is probably not directly applicable to the natural situation in which flagellates can ingest autotrophic cells (cyanobacteria) directly. In that case a greater fraction of remineralization would be attributed to protozoan grazing. 
Table 9. Simulated rates of inflow for comparison with gross production of organisms in all stages of the experimental system as percentages of the sum. The most significant flows are boxed

\begin{tabular}{|c|c|c|c|c|c|}
\hline Flow & $\mathrm{B}_{0}$ & $\mathrm{~B}_{1}$ & $\mathrm{~B}_{2}$ & $B F_{1}$ & $\mathrm{BF}$ \\
\hline \multicolumn{6}{|l|}{ (A) Bacteria } \\
\hline Inflow $\rightarrow$ Inf bact & 0 & 7 & 49 & 6 & 47 \\
\hline Inflow $\rightarrow$ Bacteria & 0 & 5 & 1 & 5 & 2 \\
\hline Carbohyd $\rightarrow \ln$ f bact & 38 & $8 \overline{6}$ & 50 & 83 & 51 \\
\hline Carbohyd $\rightarrow$ Bacteria & 62 & 2 & 0 & 6 & 1 \\
\hline \multicolumn{6}{|l|}{ (B) Virus } \\
\hline Inflow $\rightarrow$ Virus & 0 & 1 & 9 & 1 & 7 \\
\hline Inflow $\rightarrow$ Inact virus & 0 & 5 & 33 & 5 & 36 \\
\hline Cloud $\rightarrow$ Virus & $\overline{100}$ & $9 \overline{4}$ & 58 & 94 & 57 \\
\hline
\end{tabular}

Acknowledgements. This work was supported by the Swedish Natural Science Council (B-AA/BU 04452-320) and EU Project MEDIPELAGOS. Johan Wikner is acknowledged for helpful discussions on viral dynamics. We thank Richard Keil and Hugh Ducklow for reviewing the manuscript.

\section{LITERATURE CITED}

Andersson A, Lee C, Azam F, Hagström $\AA$ (1985) Release of aminoacids and inorganic nutrients by heterotrophic marine microflagellates. Mar Ecol Prog Ser 23:99-106

Azam F, Fenchel T, Field JG, Gray JS, Meyer-Rei] LA, Thingstad $F$ (1983) The ecological role of water-column microbes in the sea. Mar Ecol Prog Ser 10:257-263

Azam F, Smith DC, Steward GF, Hagström A (1.993) Bacteriaorganic matter coupling and its significance for oceanic carbon cycling. Microb Ecol

Baretta-Bekker JG, Riemann B, Baretta JW, Rasmussen EK (1994) Testing the microbial loop concept by comparing mesocosm data with results from a dynamical simulation model. Mar Ecol Prog Ser 106:187-198

Bergh Ö, Börsheim KY, Bratbak G. Heldal M (1989) High abundance of viruses found in aquatic environments. Nature 340:467-468

Bratbak G, Heldal M, Thingstad TF, Rjemann B, Haslund OH (1992) Incorporation of viruses into the budget of microbial C-transfer. A first approach. Mar Ecol Prog Ser 83:273-280

Caron DA, Goldman JC, Andersen OK, Dennett MR (1985) Nutrient cyclıng in a microflagellate food chain: II. Population dynamics and carbon cycling. Mar Ecol Prog Ser 24:243-254

Ducklow HW (1983) Production and fate of bacteria in the oceans. BioScience 33:494-501.

Fenchel T (1.987) Ecology of protozoa. The biology of free-living phagotrophic protists. Science Tech Publ, Madison, WI

Fuhrman J (1992) Bacterioplankton roles in cycling of organic matter: the microbial food web. In: Falkowski PG, Woodhead AD (eds) Primary productivity and biogeochemical cycles in the sea. Plenum Press, New York, p 361-383

Hagstrom $\AA$, Azam F, Andersson A. Wikner J, Rassoulzadegan $F$ (1988) Microbial loop in an oligotrophic pelagic marine ecosystem: possible roles of cyanobacteria and nanoflagellates in the organic fluxes. Mar Ecol Prog Ser 49:171-178

Heldal M, Bratbak G (1991) Production and decay of viruses in aquatic environments. Mar Ecol Prog Ser 72:205-212

Hempfling WP, Mainzer SE (1975) Effects of varying the carbon source limiting growth on yield and maintenance characteristics of Escherichia coli in continuious culture. J Bacteriol 123:1076-1087
Ingraham JL, Maaløe O, Neidhardt FC (1983) Growth of the bactenal cell. Sinauer Associates Inc, Sunderland

Jumars PA, Deming JW, Hill PS, Karp-Boss L, Yager PL, Dade WB (1993) Physical constraints on marme usmotrophy in an optimal foraging context. Mar Microb Food Webs 7 . $121-159$

Kepkay PE (1994) Particle aggregation and the biological reactivity of colloids. Mar Ecol Prog Ser 109:293-304

Kepkay PE, Johnson BD (1988) Microbial response to organic particles generation by surface coagulation in seawater. Mar Ecol Prog Ser 48:193-198

Kirchman DL, Suzuki Y, Garside C, Ducklow HW (1991) High turnover rates of dissolved organic carbon during a spring phytoplankton bloom. Nature 352:612-614

Neidhardt FC, Ingraham JL, Schaechter M (1990) Physiology of the bacterial cell: a molecular approach. Sinauer Associates, Inc, Sunderland, Massachusetts

Proctor LM, Fuhrman JA (1990) Viral mortality of marine bacteria and cyanobacteria. Nature 343:60-62

Proctor LM, Fuhrman JA (1991) Roles of viral infection in organic particle flux. Mar Ecol Prog Ser 69:133-142

Proctor LM, Okubo A, Fuhrman JA (1993) Calibrating estimates of phage-induced mortality in marine bacteria ultrastructural studies of marine bacteriophage development from one-step growth experiments. Mar Ecol Prog Ser 25:161-182

Rosso A, Azam F (1987) Proteolytic activity in coastal oceanic waters: depth distribution and relationship to bacterial populations. Mar Ecol Prog Ser 41:231-240

Schwartz M (1976) The adsorption of coliphage lambda to its host: effect of variations in the surface density of receptor and in phage-receptor affinity. J Mol Biol 103:521-536

Surin BP, Cox GB, Rosenberg H (1987) Molecular studies on the phosphate-specific transport system of Escherichia coll. In: Torrianı-Gorii A, Rothman FG, Silver SA Yagil E (eds) Phosphate metabolism and cellular regulation in microorganisms. American Society of Microbiology, Washington, DC, p 145-149

Suttle CA, Chan AM, Cottrell MT (1990a) Infection of phytoplankton by viruses and reduction of primary production. Nature 347:467-469

Suttle CA, Chen F (1992) Mechanisms and rates of decay of marine viruses in seawater Appl Environ Microbiol 58: $3721-3729$

Suttle CA, Fuhrman JA, Capone DG (1990b) Rapid ammonium cycling and concentration-dependent partitioning of ammonium and phosphate: implications for carbon transfer in planktonic communities. Limnol Oceanogr 35: $424-433$

Taylor AH, Joint I (1990) A steady-state analysis of the 'microbial loop' in stratified systems. Mar Ecol Prog Ser 59:1-17

Turk V, Rehnstam AS, Lundberg E, Hagström $\AA$ (1992) Release of bacterial DNA by marine nanoflagellates, an intermediate step in phosphorus regeneration. Appl Environ Microbiol 58:3744-3750

Weinbauer MG, Peduzzi P (1994) Frequency, size and distribution of bacteriophages in different marine bacterial morphotypes. Mar Ecol Prog Ser 108:11-20

Zweifel U (1993) Consumption of dissolved organic carbon by marine bacteria and demand for inorganc nutrients. Mar Ecol Prog Ser 101:23-32

Zweifel U, Blackburn NB, Hagström $\AA$ (1996) Cycling of dissolved organic matter I. An experimental system. Aquat Microb Ecol 11:65-77

Zweifel UL, Hagström $\AA$ (1995) Total counts of marine bacteria include a large fraction of non-nucleoid containing bacteria (ghosts). Appl Environ Microbiol 61:2180-2185

Manuscript first received: July 12, 1995

Revised version accepted: April 8, 1996 